\title{
KARAKTERISTIK LAHAN TAMBAK EKSISTING DI KECAMATAN PULAU DERAWAN KABUPATEN BERAU PROVINSI KALIMANTAN TIMUR
}

\author{
Hasnawi ${ }^{\#}$, Andi Indra Jaya Asaad, dan Akhmad Mustafa \\ Balai Penelitian dan Pengembangan Budidaya Air Payau \\ (Naskah diterima: 19 Juni 2014; Revisi final: 7 November 2015; Disetujui publikasi: 9 November 2015)
}

\begin{abstract}
ABSTRAK
Kabupaten Berau Provinsi Kalimantan Timur memiliki potensi lahan tambak yang cukup luas terutama di Kecamatan Pulau Derawan. Lahan tambak yang ada (eksisting) di Kecamatan Pulau Derawan terletak di sepanjang pesisir pantai yang umumnya dibangun pada lahan bekas hutan mangrove yang merupakan pulau-pulau (Delta Berau) dan hanya sebagian kecil saja yang berada di daratan utama. Kajian ini bertujuan untuk mengetahui karakteristik lahan tambak yang ada secara spasial. Metode survei diaplikasikan pada kawasan pertambakan di Kecamatan Pulau Derawan Kabupaten Berau. Parameter yang digunakan dalam menganalisis karakteristik lahan tambak adalah: kondisi tanah, kualitas air, topografi, hidrologi, dan iklim. Analisis spasial dengan penginderaan jarak jauh dan Sistem Informasi Geografis (SIG) menggunakan metode geostatistik kriging digunakan dalam menggambarkan karakteristik lahan tambak yang ada di Kecamatan Pulau Derawan Kabupaten Berau. Hasil yang diperoleh menunjukkan bahwa topografi tambak relatif landai dan elevasi tidak terlalu tinggi, tanah tergolong tanah sulfat masam, kualitas air secara umum mendukung budidaya di tambak, dan curah hujan tergolong tinggi. Hasil kajian ini diharapkan dapat digunakan untuk dasar pengelolaan lahan tambak guna meningkatkan produktivitas tambak yang berkelanjutan, serta dapat menjadi acuan pemerintah Kabupaten Berau dalam penentuan Rencana Tata Ruang Wilayah Pesisir.
\end{abstract}

KATA KUNCI: karakteristik, lahan, tambak, eksisting, Kecamatan Pulau Derawan, Kabupaten Berau

ABSTRACT: $\quad$ Land characteristics of existing brackishwater pond in Derawan Island District Berau Regency East Kalimantan Province. By: Hasnawi, Andi Indra Jaya Asaad, and Akhmad Mustafa

Berau Regency, East Kalimantan Province has large brackishwater ponds area especially in Pulau Derawan District. Existing ponds are mostly constructed in the mangrove area which is commonly found in the islands and only small part of the ponds are located in the mainland. This study aims to understand spatially the characteristic of brackishwater pond. Survey method was used to study the ponds area in the Pulau Derawan District Berau Regency. Land characteristic, water quality, topography, hydrology, and climate were the major variables that used in the spatial analysis. Kriging geostatistic method was used in this study in order to depict the characteristic of ponds in the study area. The results showed that ponds' topography was relatively slope and had a low elevation. Soil characteristic was mostly found as acid sulfat soil. The water quality variables were generally suitable for ponds' aquaculture and the rainfall was chategorized as high level. The expected outcome of this study could be applied as the basic of ponds' management in order to increase the productivity and sustainable operation. Furthermore, it can be usedas the reference for local government of Berau Regency to formulate the Coastal Land Use Planning.

KEYWORDS: characteristic, land, brackishwater pond, existing, Pulau Derawan District, Berau Regency

\section{PENDAHULUAN}

Kabupaten Berau adalah salah satu kabupaten di Provinsi Kalimantan Timur dengan perkembangan budidaya perikanannya termasuk budidaya tambak yang terus mengalami pertumbuhan dalam hal produksi dan

\# Korespondensi: Balai Penelitian dan Pengembangan Budidaya Air Payau. Jl. Makmur Dg. Sitakka No. 129, Maros 90512, Sulawesi Selatan, Indonesia. Tel.: + (0411) 371544 E-mail:vvhalowi@gmail.com luas lahan. Sebagai gambaran, pada tahun 1997 luas tambak baru 450 ha dan pada tahun 2012 mencapai 6.089 ha dengan produksi 459 ton (Wiryawan et al., 2005; Anonim, 2013). Tambak tersebut tersebar di beberapa wilayah kecamatan pesisir, antara lain; Kecamatan Pulau Derawan, Sambaliung, Talisayan, Biatan, Tabalar, dan Gunung Tabur yang digunakan untuk budidaya ikan bandeng dan udang windu (Anonim, 2009). Khusus Kecamatan Pulau Derawan, wilayahnya mencakup sebagian Delta Berau dan sebagian daratan 
utama Pulau Kalimantan dengan luas wilayah 385.900 ha (Anonim, 2013). Tambak dijumpai umumnya berada di Delta Berau tersebut yang luasnya mencapai 4.664 ha (Hasil analisis Citra satelit ALOS, akusisi, 2009). Hal ini membuat kecamatan tersebut agak berbeda dengan daerah lain di Indonesia, yang memiliki tambak berlokasi di daratan utama.

Lahan tambak di Kecamatan Pulau Derawan terletak di sepanjang pesisir pantai yang secara umum dibangun pada bekas hutan mangrove yang merupakan pulau-pulau (Delta Berau) yang dipengaruhi oleh pasang surut air laut. Secara umum, lahan estuari di Indonesia didominasi oleh tanah aluvial non-sulfat masam termasuk tanah salin, tanah sulfat masam, tanah gambut, dan masing-masing dapat memiliki karakteristik yang khas. Karakteristik lahan yang dicirikan oleh kualitas tanah, kualitas air, topografi, dan iklim adalah faktor dari karakteristik lahan yang umum dipertimbangkan untuk lahan tambak (Muir \& Kapetsky, 1988; Mustafa et al., 2007; Mustafa et al., 2010). Informasi karakteristik lahan dan distribusi spasialnya terhadap tambak yang ada di Kecamatan Pulau Derawan sangat terbatas dan belum disajikan secara spasial dalam bentuk peta.

Identifikasi dari distribusi spasial karakteristik lahan mempunyai peran penting dalam banyak sistem bio-ekologi (Zuo et al., 2008; Dong et al., 2009; Akbarzadeh \& Taghizadeh-Mehrjardi, 2010). Pengetahuan mengenai variabilitas spasial karakteristik lahan dan hubungan antar karakteristik lahan sangat diperlukan untuk evaluasi pengelolaan lahan (Huang et al., 2001), dan peningkatan keberlanjutan penggunaan lahan (Liu et al., 2006). Variabilitas adalah salah satu karakteristik hakiki dari kualitas lahan dan dalam ekosistem yang sama, kualitas lahan dapat memperlihatkan variasi spasial yang nyata (Robinson \& Metternicht, 2006). Variasi-variasi tersebut adalah terutama muncul dari faktor-faktor dan proses pedogenesis (pembentukan tanah) dan penggunaan lahan (Ersahin, 2003); serta praktekpraktek pengelolaan lahan (PanGonzalez et al., 2000; Anuar et al., 2008). Karakteristik lahan secara alami dapat berbeda-beda secara terus-menerus dalam waktu dan tempat, dan untuk kondisi seperti itu sangat sulit untuk mengukur kualitas tanah pada setiap titik di lapangan (Madyaka, 2008). Geostatistik dapat digunakan untuk menggambarkan setiap titik tersebut menjadi spasial dan mengukur variabilitas spasial dari karakteristik lahan, melakukan interpolasi secara rasional dan mengestimasi perbedaan dari nilai yang diinterpolasi (Lin et al., 2001; Essington, 2004).

Kajian ini bertujuan untuk mengetahui karakteristik lahan tambak di Kecamatan Pulau Derawan Kabupaten Berau Provinsi Kalimantan Timur.
Hasil kajian ini diharapkan dapat digunakan sebagai dasar pengelolaan lahan tambak guna meningkatkan produktivitas tambak yang berkelanjutan, serta dapat menjadi acuan Pemerintah Kabupaten Berau secara khusus dan Pemerintah Provinsi Kalimantan Timur secara umum dalam penentuan Rencana Tata Ruang Wilayah.

\section{BAHAN DAN METODE}

Penelitian ini dilaksanakan pada bulan Agustus 2010 di wilayah pesisir Kecamatan Pulau Derawan Kabupaten Berau Provinsi Kalimantan Timur. Lokasi pengambilan contoh tanah dan air meliputi kawasan pertambakan yang ada, sungai, dan saluran yang menjadi sumber pasokan air tambak (Gambar 1).

\section{Pengumpulan Data}

Data yang dikumpulkan dalam penelitian ini meliputi: topografi, tanah, air, dan iklim. Data topografi, tanah, dan air diperoleh langsung dari lapangan maupun hasil analisis di laboratorium sebagai data primer, sedangkan data iklim diperoleh dari Badan Meteorologi, Klimatologi dan Geofisika (BMKG) Kalimantan Timur sebagai data sekunder.

Topografi diketahui melalui pengamatan di lapangan dengan menggunakan Theodolit, dan dari peta Rupabumi Indonesia yang diperoleh dari Badan Informasi Geospasial (BIG). Peubah tanah yang diukur langsung di lapangan berupa kedalaman tanah dan ketebalan gambut dengan menggunakan bor tanah yang dilengkapi dengan meteran. Pengukuran dan pengambilan contoh tanah dilakukan pada kedalaman 0-0,2 m dan 0,5-0,7 m. Adapun kualitas tanah yang diukur langsung di lapangan (in situ) adalah $\mathrm{pH}_{\mathrm{F}}, \mathrm{pH}_{\mathrm{Fox}}$, dengan pH-meter dan Potensial Redoks dengan Redox-meter, sedangkan peubah yang dianalisis di Laboratorium Tanah Balai Penelitian dan Pengembangan Budidaya Air Payau (BPPBAP) Maros (ex situ), contohnya dimasukkan ke dalam kantong plastik setelah dibersihkan dari sisa tumbuhan segar dan kotoran lainnya kemudian dimasukkan ke dalam cool box yang berisi es (Ahern et al., 2004). Peubah tanah yang diukur tersebut antara lain; $\mathrm{pH}_{\mathrm{KCl}}, \mathrm{pH}_{\mathrm{OX}}, \mathrm{S}_{\mathrm{P}}, \mathrm{S}_{\mathrm{KCl}}$, $\mathrm{S}_{\mathrm{POS}}$, TPA, TAA, TSA, pirit, karbon organik, $\mathrm{N}$-total, $\mathrm{PO}_{4}$, Fe, Al, dan tekstur mengikuti petunjuk McElnea \& Ahern (2004a, 2004b, 2004c, 2004d), Melville (1993), Ahern \& McElnea (2004), Ahern et al. (1998a, 1998b), Sulaeman et al. (2005), Menon (1973), dan Abdurachman et al. (2006).

Pengukuran dan pengambilan contoh air dilakukan di sungai, saluran, dan tambak. Pengukuran dan pengambilan contoh air di tambak mengikuti titik pengambilan contoh tanah. Jumlah titik contoh tanah dan air masing-masing 46 dan 48 (Gambar 1). Peubah 


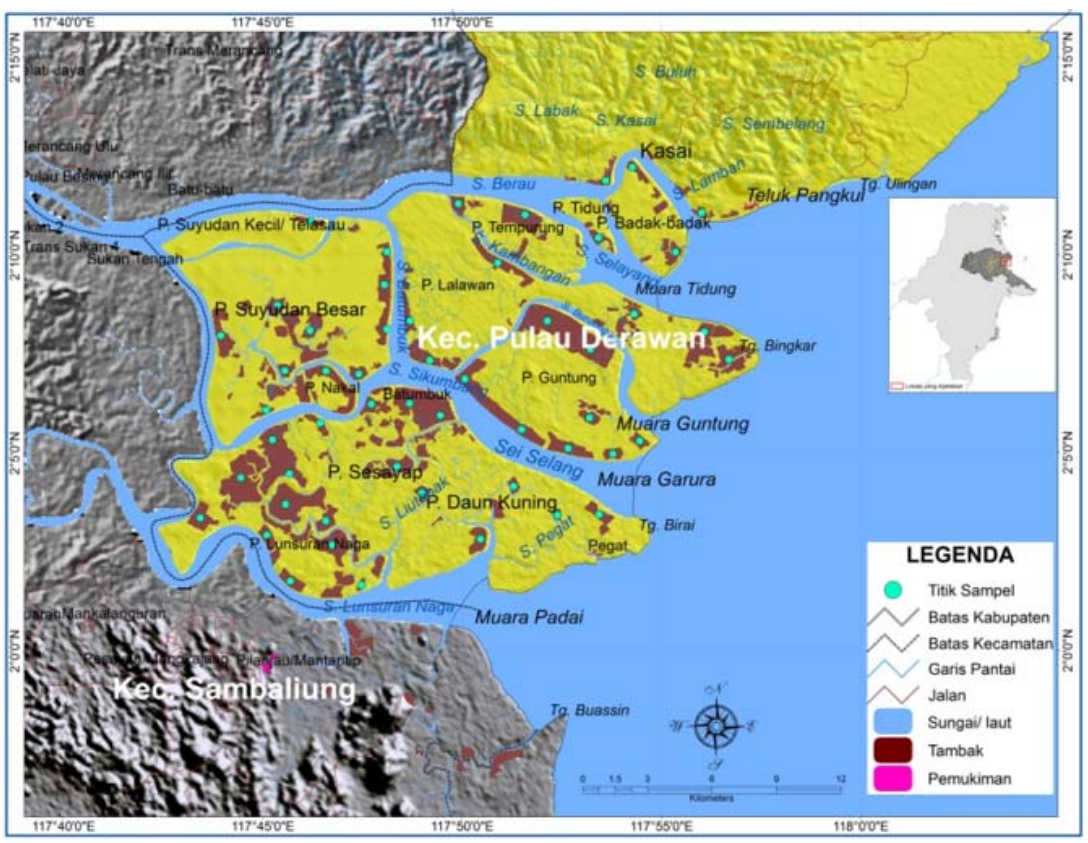

Gambar 1. Lokasi penelitian dan titik-titik pengamatan dan pengambilan contoh tanah dan air di kawasan pesisir Kecamatan Pulau Derawan Kabupaten Berau Provinsi Kalimantan Timur

Figure 1. Study area and distribution of sampling points of soil and water in Derawan Island District Berau Regency East Kalimantan Province

kualitas air yang diukur langsung di lapangan adalah suhu, salinitas, oksigen terlarut, dan $\mathrm{pH}$ dengan menggunakan Hydrolab ${ }^{\circledR}$ Minisonde. Contoh air untuk analisis di laboratorium diambil dengan menggunakan Kemmerer Water Sampler dan dipreservasi mengikuti petunjuk APHA (2005). Peubah kualitas air yang dianalisis di Laboratorium Air BPPBAP di Maros meliputi: $\mathrm{NH}_{4}, \mathrm{NO}_{3}, \mathrm{NO}_{2}, \mathrm{PO}_{4}, \mathrm{Fe}$, bahan organik total, dan padatan terlarut total mengikuti petunjuk Menon (1973), Parsons et al. (1989) dan APHA (2005).

\section{Analisis Data}

Data peubah karakteristik lahan dianalisis dengan metode statistik klasik untuk mendapatkan minimum, maksimum, rata-rata, dan standar deviasi berdasarkan petunjuk Sokal \& Rohlf(1981). Metode Kriging dengan geostatistik dalam perangkat lunak ArcGIS 9.3 digunakan dalam interpolasi terhadap data tanah yang ada pada kedalaman tanah 0-0,2 m (permukaan) untuk mendapatkan distribusi spasial setiap karakteristik tanah dan air. Interpolasi data hanya dilakukan pada permukaan tanah karena pada lapisan ini terjadi pengolahan tanah selama proses budidaya dan terjadi kontak langsung dengan air yang masuk ke dalam petakan tambak sehingga berpengaruh pula pada kualitas airnya.

\section{HASIL DAN BAHASAN}

\section{Karakteristik Lahan}

Lahan merupakan suatu lingkungan fisik yang terdiri atas topografi, tanah, hidrologi, vegetasi, dan iklim. Oleh karena itu, perbedaan kombinasi penyusun lingkungan fisik lahan tersebut akan memberikan karakteristik lahan yang berbeda.

\section{Topografi}

Kemiringan lereng dan elevasi adalah faktor penting yang memengaruhi topografi lahan dalam hubungan dengan budidaya tambak. Secara umum, kemiringan lereng lahan tambak di Kecamatan Pulau Derawan Kabupaten Berau kurang dari $2 \%$, yang menunjukkan bahwa kemiringan lereng lahan tambak dapat mendukung usaha budidaya air payau yang dikelola secara tradisional. Lereng yang landai ini ditunjang juga oleh elevasi yang relatif rendah sehingga pemasukan dan pengeluaran air secara gravitasi atau melalui pasang surut masih dapat dilakukan. Sekitar $3,74 \%$ atau $1.276,35 \mathrm{~km}^{2}$ lahan di Kabupaten Berau yang memiliki elevasi 0-7 m (Gambar 2). Tambak di Kecamatan Pulau Derawan sebagian besar dibangun pada pulau-pulau bekas kawasan mangrove yang terjangkau oleh pasang surut. Tambak yang baik, 


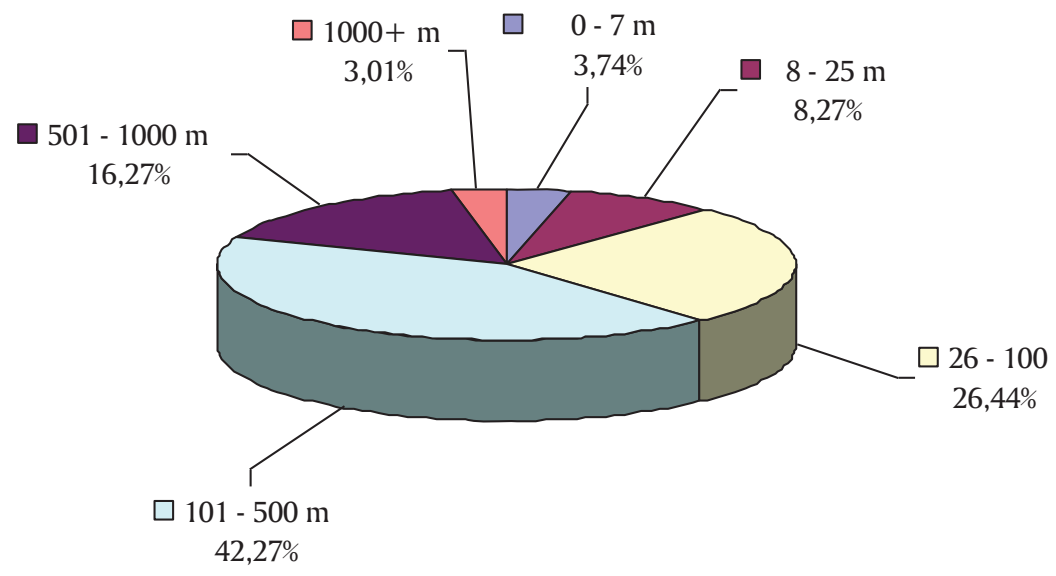

Gambar 2. Persentase luas lahan pada berbagai elevasi tanah di Kabupaten Berau Provinsi Kalimantan Timur (diolah dari Anonim, 2009)

Figure 2. The percentage of total land at various elevations in Berau Regency East Kalimantan Province (analyzed from Anonymous, 2009)

memiliki kemiringan yang relatif datar dan berelevasi rendah sehingga penggalian dapat diminimalkan namun dapat diperoleh kedalaman air tambak yang dikehendaki.

Pasang surut adalah faktor yang menentukan kemampuan suatu tambak untuk dapat digenangi secara gravitasi. Kisaran pasang surut yang ideal untuk tambak adalah antara 1,5 $\mathrm{m}$ dan 2,5 $\mathrm{m}$ (Mustafa et al., 2008). Daerah pantai dengan kisaran pasang surut kurang dari $1 \mathrm{~m}$ sangat sulit untuk pengisian maupun pengeluaran air secara gravitasi. Sebaliknya daerah pantai yang kisaran pasang surutnya lebih dari $3 \mathrm{~m}$ juga terlalu berat untuk budidaya di tambak, sebab pematang harus dibuat besar dan tinggi agar mampu menahan tekanan air saat pasang tinggi dan surut rendah (Mustafa et al., 2007). Hasil pengukuran pasang surut di kawasan tambak Kecamatan Pulau Derawan menunjukkan kisaran pasang surut mencapai 2,77 m dan tergolong kurang mendukung untuk tambak (Gambar 3). Pasang surut yang demikian membutuhkan pematang yang agak tinggi dan lebar, serta kokoh agar pematang dapat menahan tekanan air dari dalam tambak maupun tekanan air dari luar tambak.

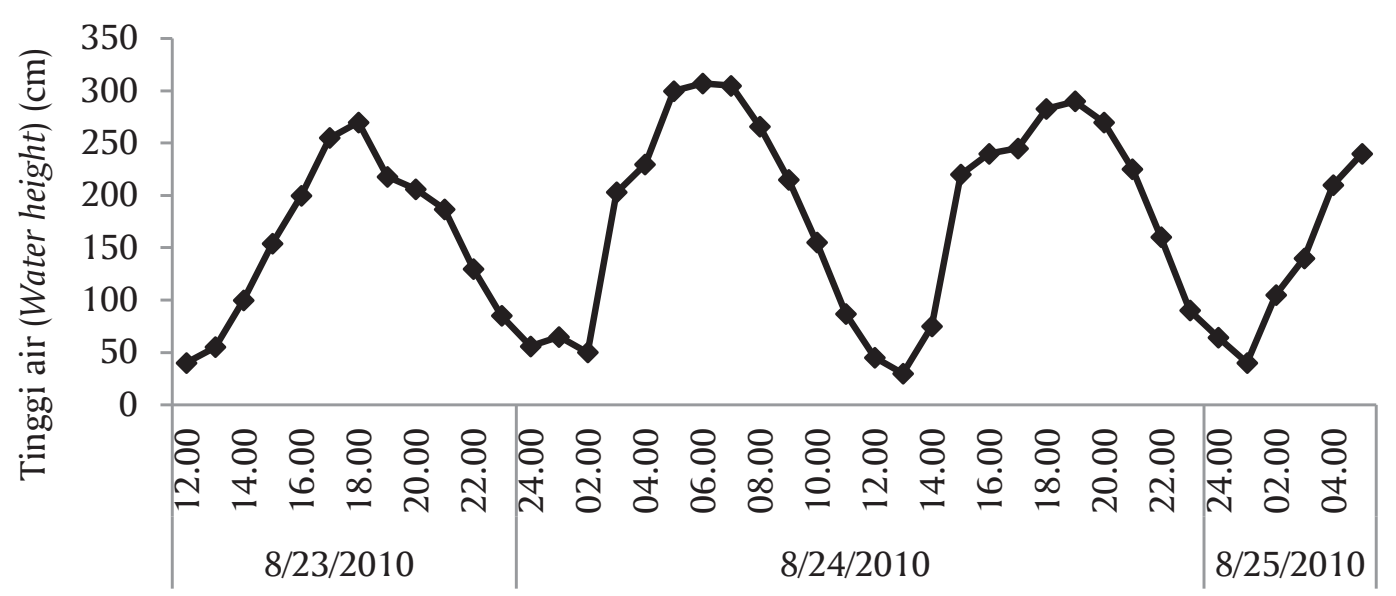

Waktu pengamatan (Observation time)

Gambar 3. Pasang surut yang terukur pada tanggal 23-25 Agustus 2010 di Kecamatan Pulau Derawan Kabupaten Berau Provinsi Kalimantan Timur

Figure 3. Tidal conditions in Derawan Island District Berau Regency East Kalimantan Province (Data was measured on August 23-25, 2010) 
Chanratchakool et al. (1995) menyarankan lahan yang baik untuk budidaya tambak adalah relatif datar. Lokasi tambak sebaiknya dipilih di tempat yang mempunyai elevasi 2-4 m (Mustafa et al., 2008) agar memudahkan pengelolaan air, sehingga tambak cukup mendapatkan air pada saat terjadi pasang harian dan dapat dikeringkan pada saat surut harian (Poernomo, 1989).

\section{Kondisi Tanah}

Berdasarkan pada taksonomi tanah (Soil Survey Staff, 2001), tanah tambak di Kecamatan Pulau Derawan diklasifikasikan sebagai sulfaquent dan sulfihemits untuk kategori kelompok besar (great groups). Sulfaquent dicirikan dengan aquents yang mempunyai bahan sulfidik atau pirit sampai 0,5 m dari permukaan tanah dan termasuk tanah sulfat masam potensial. Dalam kategori kelompok inti (ordo), sulfaquent dimasukkan dalam entisol atau pada sistem klasifikasi tanah dari Pusat Penelitian Tanah dimasukkan dalam tanah Aluvial. Tanah sulfat masam tidak hanya didapatkan dalam tanah mineral, tetapi juga dalam tanah organik, termasuk tanah sulfat masam di Kabupaten Mamuju yang diklasifikasi sebagai sulfihemits (Mustafa et al., 2010). Sulfihemits dicirikan dengan keberadaan bahan sulfidik sampai $1,0 \mathrm{~m}$ dari permukaan yang tidak teroksidasi dan tidak mempunyai horizon sulfurik pada kedalaman 0,5 m dari permukaan tanah, serta juga digolongkan sebagai tanah sulfat masam potensial. Dalam kategori kelompok inti, sulfihemits adalah histosol atau pada sistem klasifikasi tanah dari Pusat Penelitian Tanah dimasukkan dalam organosol.

Kualitas tanah tambak secara keseluruhan di Kecamatan Pulau Derawan dapat dilihat pada Tabel 1 dan Gambar 4-6 untuk kedalaman 0-0,2 m dan Tabel 2 untuk kedalaman 0,5-0,7 m. Potensial redoks tanah menunjukkan status tanah yang teroksidasi atau tereduksi. Potensial redoks adalah hasil pengukuran kuantitatif untuk menginformasikan suatu indeks diagnostik dari tingkat anaerobik atau anoksia tanah (Patrick \& Delaune, 1977). Potensial redoks adalah salah satu peubah penting dalam mengontrol persistensi berbagai senyawa organik dan anorganik tanah (Zhang et al., 2009). Potensial redoks tanah secara umum bernilai negatif, baik pada kedalaman 00,2 $\mathrm{m}$ dan 0,5-0,7 m yang menunjukkan bahwa tanah tambak di Kecamatan Pulau Derawan tergolong dalam keadaan tereduksi. Hal ini sebagai akibat, pada saat pengukuran umumnya tambak terisi air sebab tambak sedang digunakan untuk budidaya udang windu, ikan bandeng, dan atau polikultur keduanya (Gambar 4a).

$\mathrm{pH}_{\mathrm{F}}$ dapat digunakan untuk indikator secara cepat akan keberadaan dan kepelikan tanah sulfat masam aktual (Gambar 4b). Secara umum, $\mathrm{pH}_{\mathrm{F}}$ tanah tambak pada kedalaman 0-0,2 m lebih tinggi daripada kedalaman 0,5-0,7 m. Hal ini diduga sebagai akibat lebih intensifnya pembilasan tanah secara alami pada permukaan tambak daripada kedalaman tanah di bawahnya untuk waktu yang cukup lama yang menyebabkan lebih banyaknya unsur atau senyawa
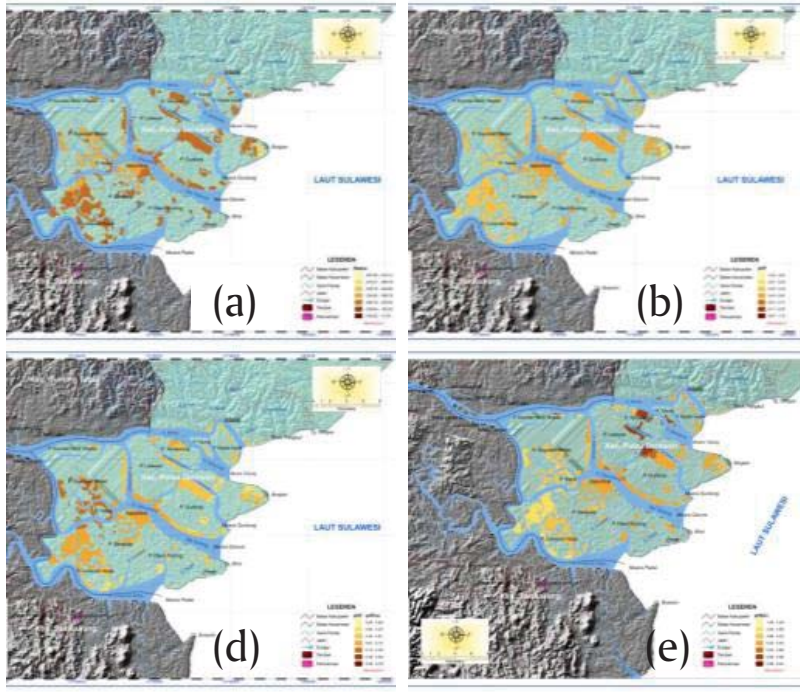

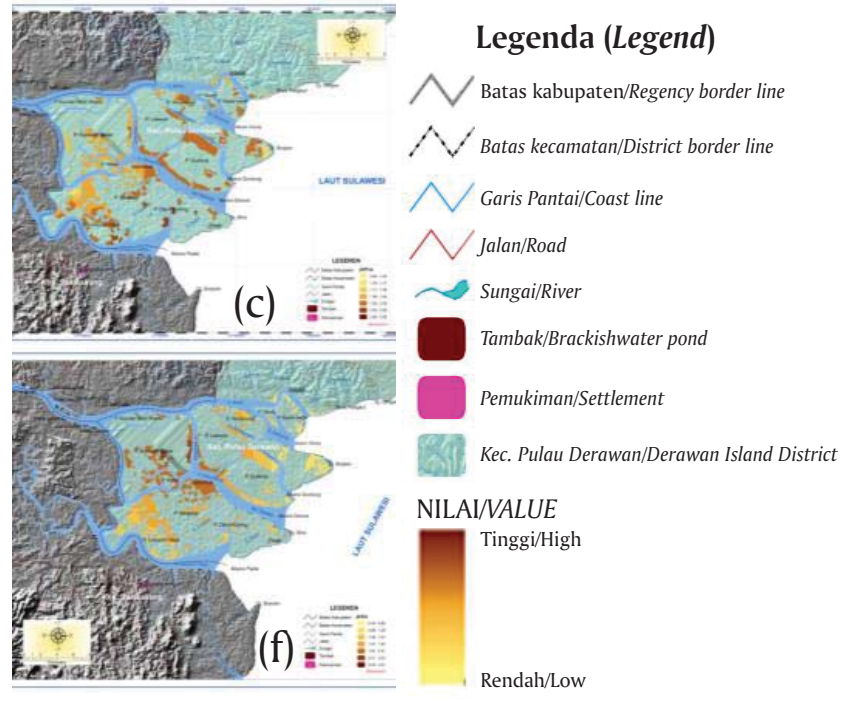

Gambar 4. Peta tematik masing-masing parameter tanah tambak di Kecamatan Pulau Derawan Kabupaten Berau Provinsi Kalimantan Timur: (a) potensial redoks (mV), (b) $\mathrm{pH}_{\mathrm{F}}$, (c) $\mathrm{pH}_{\mathrm{Fox}}$, (d) $\mathrm{pH}_{\mathrm{F}}-\mathrm{pH}_{\mathrm{FOX}}$, (e) $\mathrm{pH}_{\mathrm{KCl}}$, (f) $\mathrm{pH}_{\mathrm{OX}}$

Figure 4. Thematic map of brackishwater pond soil for each parameter in Derawan Island District Berau Regency East Kalimantan Province: (a) redox potential (mV), (b) $p H_{F}$, (c) $p H_{F O X}$, (d) $p H_{F}-p H_{F O X}$, (e) $p H_{K C \text { P }}$ (f) $p H_{O X}$ 
Tabel 1. Kualitas tanah tambak pada kedalaman 0-0,2 $\mathrm{m}(\mathrm{n}=46)$ di Kecamatan Pulau Derawan Kabupaten Berau Provinsi Kalimantan Timur

Table 1. Soil quality at 0-0.2 $\mathrm{m}$ depth $(n=46)$ in brackishwater ponds in Derawan Island District Berau Regency East Kalimantan Province

\begin{tabular}{|c|c|c|c|c|}
\hline $\begin{array}{l}\text { Peubah } \\
\text { Variables }\end{array}$ & $\begin{array}{l}\text { Minimum } \\
\text { Minimum }\end{array}$ & $\begin{array}{l}\text { Maksimum } \\
\text { Maximum }\end{array}$ & $\begin{array}{l}\text { Rata-rata } \\
\text { Average }\end{array}$ & $\begin{array}{l}\text { Standar deviasi } \\
\text { Standard deviation }\end{array}$ \\
\hline $\begin{array}{l}\text { Potensial redoks } \\
\text { Redox potential (mV) }\end{array}$ & -387 & -78 & -283 & 84 \\
\hline $\mathrm{pH}_{\mathrm{F}}$ & 5.2 & 7.17 & 6.51 & 0.337 \\
\hline $\mathrm{pH}_{\mathrm{FOX}}$ & 0.85 & 3.56 & 1.797 & 0.7728 \\
\hline $\mathrm{pH}_{\mathrm{F}}-\mathrm{pH}_{\mathrm{FOX}}$ & 2.63 & 5.79 & 4.713 & 0.8375 \\
\hline $\mathrm{pH}_{\mathrm{KCl}}$ & 1.49 & 6.54 & 5.202 & 1.1408 \\
\hline $\mathrm{pH}_{\mathrm{OX}}$ & 0.25 & 5.3 & 1.946 & 1.1395 \\
\hline $\mathrm{S}_{\mathrm{KCl}}(\%)$ & 0.1 & 1.21 & 0.405 & 0.2697 \\
\hline $\mathrm{S}_{\mathrm{P}}(\%)$ & 0 & 3.82 & 1.598 & 0.9588 \\
\hline $\mathrm{S}_{\mathrm{POS}}(\%)$ & 0.22 & 2.85 & 1.193 & 0.766 \\
\hline $\mathrm{TPA}\left(\mathrm{mol} \mathrm{H}^{+} /\right.$ton $)$ & 0 & $1,000.00$ & 295.75 & 245.476 \\
\hline $\mathrm{TAA}\left(\mathrm{mol} \mathrm{H}^{+} /\right.$ton $)$ & 0 & 114 & 7.2 & 20.629 \\
\hline $\mathrm{TSA}$ (mol H${ }^{+} /$ton) & 12 & 921 & 288.55 & 231.224 \\
\hline Pirit (Pyrite) (\%) & 0.05 & 4.11 & 1.288 & 1.0323 \\
\hline $\mathrm{Fe}(\mathrm{mg} / \mathrm{L})$ & 122 & $4,958.00$ & $3,620.41$ & $1,625.74$ \\
\hline $\mathrm{Al}(\mathrm{mg} / \mathrm{L})$ & 40 & 739.5 & 361.739 & 159.1925 \\
\hline $\begin{array}{l}\text { Bahan organik } \\
\text { Organic matter (\%) }\end{array}$ & 1.94 & 14.63 & 6.64 & 3.1394 \\
\hline $\begin{array}{l}\text { Nitrogen total } \\
\text { Total nitrogen (\%) }\end{array}$ & 0.31 & 0.78 & 0.467 & 0.0938 \\
\hline Rasio C:N (C:N ratio ) & 3.61 & 16.14 & 8.026 & 2.9513 \\
\hline $\mathrm{PO}_{4}(\mathrm{mg} / \mathrm{L})$ & 9.13 & 68.17 & 23.037 & 12.9111 \\
\hline Pasir (Sand) (\%) & 38 & 62 & 48 & 5.32 \\
\hline Debu (Silt) $(\%)$ & 14 & 50 & 32.1 & 8.74 \\
\hline Liat (Clay) (\%) & 0 & 40 & 20 & 11.29 \\
\hline $\begin{array}{l}\text { Tekstur } \\
\text { Texture }\end{array}$ & \multicolumn{4}{|c|}{$\begin{array}{l}\text { Lempung berpasir ( } 26.09 \%) \text {, lempung }(39.13 \%) \text {, } \\
\text { lempung berdebu }(6.52 \%) \text {, lempung berliat }(8.70 \%) \text {, } \\
\text { lempung liat berpasir }(19.57 \%) \\
\text { Sandy loam }(26.09 \%) \text {, clay (39.13\%), silty clay }(6.52 \%) \text {, } \\
\text { clayey loam }(8.70 \%), \text { sandy clay loam }(19.57 \%)\end{array}$} \\
\hline
\end{tabular}

penyebab kemasaman yang terbilas pada bagian permukaan tambak. Berbeda dengan hasil pengukuran $\mathrm{pH}_{\mathrm{F}}$ adalah hasil pengukuran $\mathrm{pH}_{\mathrm{FOX}}$ yaitu $\mathrm{pH}$ yang diukur di lapangan setelah tanah diberikan $\mathrm{H}_{2} \mathrm{O}_{2} 30 \%$. Pemberian $\mathrm{H}_{2} \mathrm{O}_{2} 30 \%$ dalam pengukuran $\mathrm{pH}_{\text {FOX }}$ dimaksudkan agar potensi kemasaman yang ada dalam tanah dapat teroksidasi seluruhnya secara paksa (Gambar 4c). Sebagai akibatnya $\mathrm{pH}_{\mathrm{Fox}}$ yang terukur menjadi lebih rendah daripada hasil pengukuran $\mathrm{pH}_{\mathrm{F}}$. Nilai $\mathrm{pH}_{\mathrm{Fox}}$ tanah permukaan tambak lebih tinggi daripada tanah yang ada di bawahnya.
Nilai $\mathrm{pH}_{\mathrm{F}}-\mathrm{pH}_{\mathrm{FOX}}$ dapat digunakan sebagai indikator besarnya nilai potensi kemasaman pada tanah sulfat masam. Dari Tabel 1 dan 2 terlihat bahwa potensi kemasaman tanah lebih tinggi pada kedalaman 0,5$0,7 \mathrm{~m}$ yang ditunjukkan dengan nilai $\mathrm{pH}_{\mathrm{F}}-\mathrm{pH}_{\mathrm{FOX}}$ yang lebih tinggi daripada permukaan tanah. Secara umum potensi kemasaman yang rendah dijumpai di kecamatan yang berada di pulau utama, hal ini diduga karena tanah di pulau utama berumur lebih tua dibandingkan di pulau-pulau (delta) yang berumur lebih muda, dan terbentuk dari hasil pelapukan material yang 
Tabel 2. Kualitas tanah tambak pada kedalaman 0,5-0,7 m $(\mathrm{n}=46)$ di Kecamatan Pulau Derawan Kabupaten Berau Provinsi Kalimantan Timur

Table 2. Soil quality at 0.5-0.7 $\mathrm{m}$ depth $(n=46)$ in brackishwater ponds in Derawan Island District Berau Regency East Kalimantan Province

\begin{tabular}{|c|c|c|c|c|}
\hline $\begin{array}{c}\text { Peubah } \\
\text { Variables }\end{array}$ & $\begin{array}{l}\text { Minimum } \\
\text { Minimum }\end{array}$ & $\begin{array}{l}\text { Maksimum } \\
\text { Maximum }\end{array}$ & $\begin{array}{l}\text { Rata-rata } \\
\text { Average }\end{array}$ & $\begin{array}{l}\text { Standar deviasi } \\
\text { Standard deviation }\end{array}$ \\
\hline $\begin{array}{l}\text { Potensial redoks } \\
\text { Redox potential (mV) }\end{array}$ & -387 & -149 & -312.7 & 59.43 \\
\hline $\mathrm{pH}_{\mathrm{F}}$ & 6.12 & 7.15 & 6.532 & 0.2113 \\
\hline $\mathrm{pH}_{\mathrm{FOX}}$ & 0.62 & 3.43 & 1.492 & 0.6541 \\
\hline $\mathrm{pH}_{\mathrm{F}}-\mathrm{pH}_{\mathrm{FOX}}$ & 3.15 & 6.06 & 5.04 & 0.6811 \\
\hline $\mathrm{pH}_{\mathrm{KCl}}$ & 1.51 & 6.48 & 4.251 & 1.3656 \\
\hline $\mathrm{pH}_{\mathrm{OX}}$ & 0.04 & 7.36 & 1.578 & 1.5675 \\
\hline $\mathrm{S}_{\mathrm{KCl}}(\%)$ & 0.11 & 1.28 & 0.564 & 0.3219 \\
\hline$S_{P}(\%)$ & 0.18 & 4.06 & 2.35 & 0.9864 \\
\hline $\mathrm{S}_{\mathrm{POS}}(\%)$ & 0.07 & 3.14 & 1.786 & 0.7859 \\
\hline TPA ( $\mathrm{mol} \mathrm{H}^{+} /$ton $)$ & 0 & $1,014.00$ & 480.96 & 271.275 \\
\hline $\mathrm{TAA}\left(\mathrm{mol} \mathrm{H}^{+} /\right.$ton $)$ & 0 & 107 & 18.4 & 24.168 \\
\hline $\mathrm{TSA}\left(\mathrm{mol} \mathrm{H}^{+} /\right.$ton $)$ & 41 & 959 & 462.55 & 256.829 \\
\hline Pirit (Pyrite) $(\%)$ & 0.18 & 4.28 & 2.065 & 1.1466 \\
\hline $\mathrm{Fe}(\mathrm{mg} / \mathrm{L})$ & 44 & $5,010.00$ & $4,081.94$ & $1,371.68$ \\
\hline $\mathrm{Al}(\mathrm{mg} / \mathrm{L})$ & 18 & 814.5 & 453.196 & 164.6746 \\
\hline $\begin{array}{l}\text { Bahan organik } \\
\text { Organic matter }(\%)\end{array}$ & 2.08 & 14.26 & 7.946 & 3.0123 \\
\hline $\begin{array}{l}\text { Nitrogen total } \\
\text { Total nitrogen }(\%)\end{array}$ & 0.29 & 0.64 & 0.465 & 0.0749 \\
\hline Rasio C:N (C:N ratio ) & 4.15 & 17.21 & 9.807 & 3.2511 \\
\hline $\mathrm{PO}_{4}(\mathrm{mg} / \mathrm{L})$ & 2.24 & 76.66 & 31.113 & 18.1566 \\
\hline Pasir (Sand) $(\%)$ & 34 & 60 & 48.1 & 5.62 \\
\hline Debu (Silt) $(\%)$ & 2 & 64 & 36.1 & 11.95 \\
\hline Liat (Clay) (\%) & 0 & 50 & 15.7 & 13.63 \\
\hline $\begin{array}{l}\text { Tekstur } \\
\text { Texture }\end{array}$ & \multicolumn{4}{|c|}{$\begin{array}{l}\text { Lempung berpasir }(28.26 \%) \text {, lempung }(30.43 \%), \\
\text { lempung berdebu }(13.04 \%) \text {, lempung berliat }(13.04 \%), \\
\text { lempung liat berpasir }(15.22 \%) \\
\text { Sandy loam }(28.26 \%) \text {, clay }(30.43 \%) \text {, silty clay }(13.04 \%), \\
\text { clayey loam }(13.04 \%) \text {, sandy clay loam }(15.22 \%)\end{array}$} \\
\hline
\end{tabular}

berasal dari pulau utama kemudian terbawa oleh sungai dan mengendap di laut (muara sungai) (Gambar 4d).

Pada tanah sulfat masam yang dicirikan dengan kandungan pirit, maka salah satu sumber kemasamannya adalah sulfur. Pirit yang teroksidasi akan menghasilkan asam sulfat dan ferrosulfat yang apabila bereaksi dengan air melepaskan ferrisulfat yang selanjutnya apabila teroksidasi kembali akan menghasilkan asam sulfat. Hasil analisis sulfur $\left(\mathrm{S}_{\mathrm{KC}}\right.$, $\left.S_{P}, S_{P O S}\right)$ yang diekstrak dengan pengekstrak yang berbeda menunjukkan bahwa kandungan sulfur yang lebih rendah dijumpai pada permukaan tanah tambak. Sebagai sumber kemasaman yang penting pada tanah sulfat masam, maka sulfur yang diukur dalam bentuk $\mathrm{S}_{\mathrm{POS}}$ tanah telah digunakan oleh Ahern et al. (1998b) untuk menentukan kebutuhan kapur bagi tanah sulfat masam (Gambar 5a-c).

Hasil pengukuran peubah lain yang menggambarkan kemasaman tanah yaitu TPA, TAA, dan TSA (Gambar $5 d-f)$, menunjukkan kecenderungan pola yang sama dengan peubah kemasaman tanah lainnya seperti $\mathrm{pH}_{\mathrm{F}}-$ $\mathrm{pH}_{\mathrm{FOX}}, \mathrm{S}_{\mathrm{KCl}}, \mathrm{S}_{\mathrm{P}}, \mathrm{S}_{\mathrm{POS}}$. Hal ini juga menunjukkan bahwa 

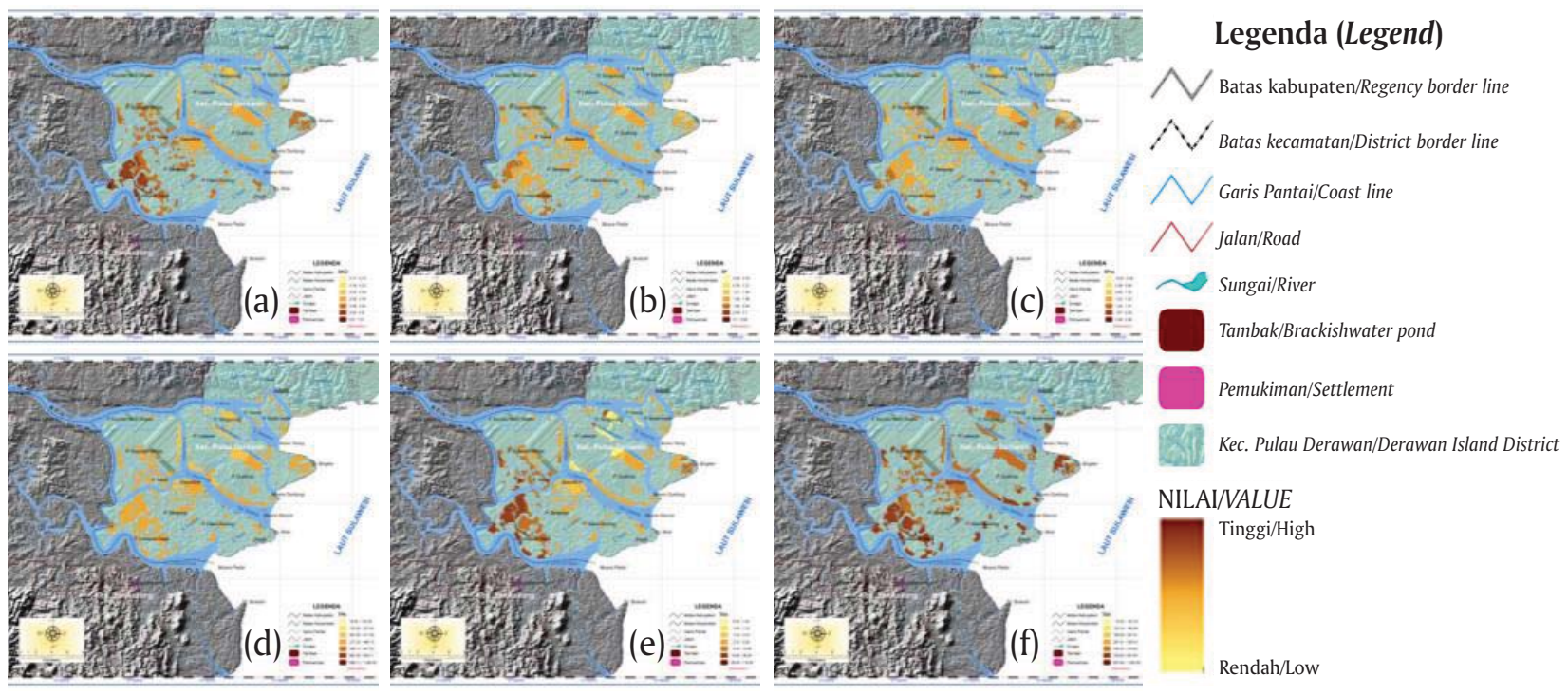

Gambar 5. Peta tematik masing-masing parameter tanah tambak di Kecamatan Pulau Derawan Kabupaten Berau Provinsi Kalimantan Timur: (a) $S_{\mathrm{KCl}}(\%)$, (b) $\mathrm{S}_{\mathrm{p}}(\%)$, (c) $\mathrm{S}_{\mathrm{POS}}(\%)$, (d) TPA $\left(\mathrm{mol} \mathrm{H}^{+} /\right.$ton), (e) TAA (mol H $\mathrm{H}^{+}$ton), (f) TSA (mol H+ ton)

Figure 5. Thematic map of brackishwater pond soil for each parameter in Derawan Island District Berau Regency East Kalimantan Province: (a) $S_{K C l}(\%)$, (b) $S_{P}(\%)$, (c) $S_{P O S}(\%)$, (d) TPA (mol H+/ton), (e) TAA (mol H+/ton), (f) TSA ( $\mathrm{mol} \mathrm{H}^{+} /$ton)

TPA, TAA, dan TSA yang rendah juga dijumpai pada permukaan tanah tambak dibandingkan dengan kedalaman tanah 0,5-0,7 m. Telah dikatakan oleh McElnea et al. (2002a, 2002b) bahwa pada tanah sulfat masam yang rendah kandungan bahan organiknya, maka TSA berkorelasi baik dengan $S_{\text {POS }}$. TSA juga mempunyai hubungan secara liniar dengan kandungan pirit (Sutrisno, 1990 dalam Noor, 2004) pada tanah sulfat masam.

Pirit adalah ciri utama dari tanah sulfat masam. Kandungan pirit tanah tambak di Kecamatan Pulau Derawan sangat kontras antara permukaan tanah dan kedalaman tanah 0,5-0,7 m. Kandungan pirit yang rendah didapatkan pada permukaan tanah tambak (Gambar 6a). Salah satu penyebab rendahnya kandungan pirit yang ada di permukaan tanah karena pirit tersebut teroksidasi di mana hasil oksidasinya terbuang bersama air rendaman tambak. Faktor yang diduga menyebabkan tingginya kandungan pirit pada kedalaman 0,5-0,7 $\mathrm{m}$ adalah faktor yang memengaruhi pembentukan pirit. Faktor-faktor yang memengaruhi pembentukan pirit adalah jumlah bahan organik, suhu sedimen, pasokan $\mathrm{SO}_{4}$ dan bikarbonat, serta suasana anaerob dan kandungan Fe (Dent, 1986). Tingginya kandungan pirit tanah pada kedalaman 0,5-0,7 m karena memiliki kandungan bahan organik yang lebih tinggi yang merupakan sumber karbon bagi bakteri dalam pembentukan pirit. Suasana anaerob merupakan kondisi yang lebih umum pada kedalaman tanah 0,5-
0,7 $\mathrm{m}$ yang juga memicu pembentukan pirit pada kedalaman ini.

Kandungan $\mathrm{Fe}$ dan $\mathrm{Al}$ tanah permukaan tambak lebih rendah daripada tanah pada kedalaman 0,5-0,7 $\mathrm{m}$. Kandungan Al pada tanah sulfat masam meningkat pada $\mathrm{pH}$ yang lebih rendah, yaitu $\mathrm{pH}$ 4,0-4,5 (Dent, 1986). Selain itu, kandungan Al pada tanah sulfat masam berkaitan dengan oksidasi pirit (Gambar 6b, c). Suasana yang sangat masam mempercepat pelapukan mineral alumino-silikat akibat perusakan kisi dari mineral tipe 2:2 (seperti montmorillonit) menjadi mineral tipe 1:1 (kaolinit) dengan membebaskan dan melarutkan Al yang lebih banyak (Pons, 1973).

Kandungan $\mathrm{N}$-total tanah yang tinggi juga dijumpai pada kedalaman tanah 0,5-0,7 m. Bahan organik, selain sebagai sumber karbon, juga merupakan sumber nitrogen (Boyd, 2008). Juga terlihat adanya kecenderungan lebih tingginya kandungan fosfat tanah pada kedalaman 0,5-0,7 m.

Tekstur tanah merupakan perbandingan antara fraksi pasir, liat, dan debu tanah. Di antara ketiga fraksi tanah tersebut, maka fraksi pasir lebih dominan dibandingkan fraksi tanah lainnya yaitu 48,0\% pada pemukaan tanah tambak dan $48,1 \%$ pada kedalaman tanah 0,5-0,7 m. Dari Tabel 1 dan 2 terlihat pula bahwa tekstur yang dominan pada permukaan tanah maupun kedalaman tanah 0,5-0,7 $\mathrm{m}$ adalah lempung dan lempung berpasir. 

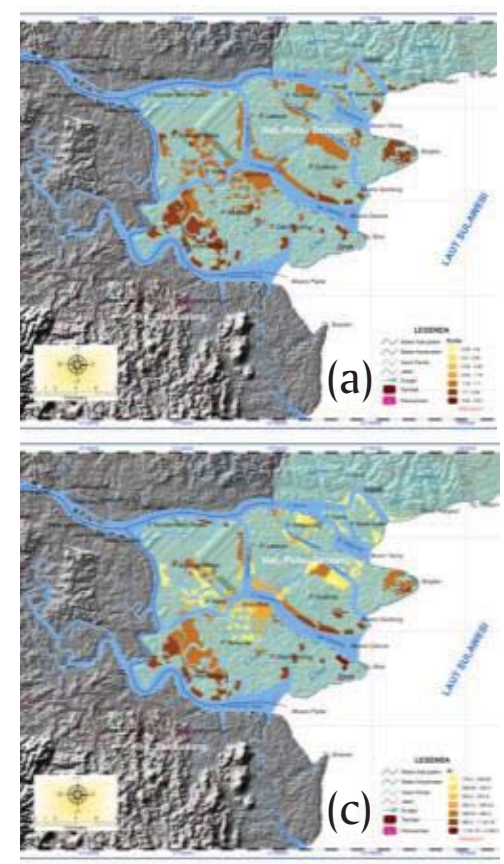
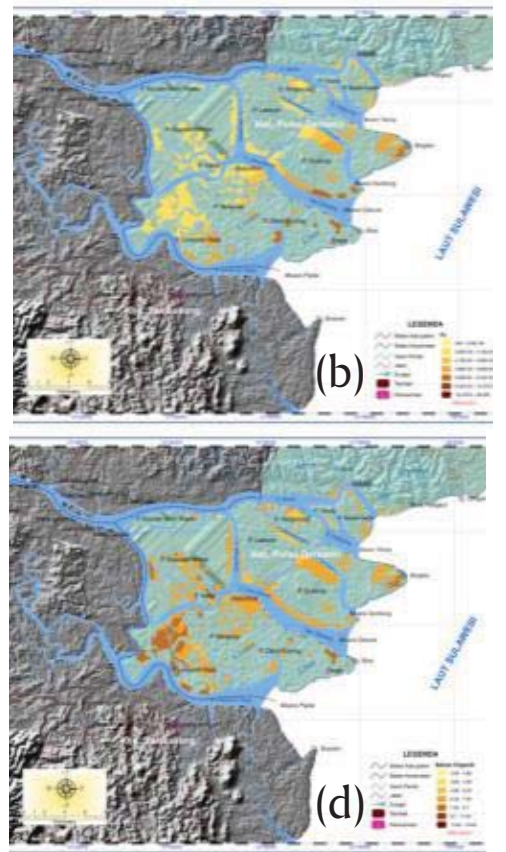

\section{Legenda (Legend)}

$\checkmark$ Batas kabupaten/Regency border line A Batas kecamatan/District border line $\checkmark$ Garis Pantai/Coast line

$\checkmark$ Jalan/Road

Sungai/River

Tambak/Brackishwater pond

Pemukiman/Settlement

Q94] Kec. Pulau Derawan/Derawan Island District

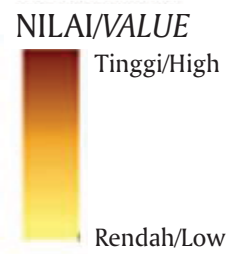

Gambar 6. Peta tematik masing-masing parameter tanah tambak di Kecamatan Pulau Derawan Kabupaten Berau Provinsi Kalimantan Timur: (a) pirit (\%), (b) besi (mg/L), (c) aluminium (mg/L), (d) bahan organik (\%)

Figure 6. Thematic map of brackishwater pond soil for each parameter in Derawan Island District Berau Regency East Kalimantan Province: (a) pyrite (\%), (b) fe (mg/L), (c) aluminium (mg/L), (d) organic matter (\%)

\section{Kualitas Air}

Fluktuasi suhu yang dapat menimbulkan masalah adalah fluktuasi suhu harian. Perbedaan suhu antara siang dan malam hari cukup besar terutama pada tambak-tambak dangkal yaitu $10^{\circ} \mathrm{C}$. Suhu air yang layak untuk budidaya udang windu berkisar antara $26^{\circ} \mathrm{C}-32^{\circ} \mathrm{C}$ dan optimalnya antara $29^{\circ} \mathrm{C}-30^{\circ} \mathrm{C}$. Suhu optimal untuk pertumbuhan ikan bandeng dan udang vaname adalah $28^{\circ} \mathrm{C}-30^{\circ} \mathrm{C}$, dan untuk budidaya rumput laut adalah $25^{\circ} \mathrm{C}-30^{\circ} \mathrm{C}$ (Mustafa et al., 2008). Secara umum, suhu air tambak di Kecamatan Pulau Derawan masih mendukung usaha budidaya di tambak (Tabel 3, Gambar 7a).

Pengaruh langsung salinitas terhadap organisme akuatik adalah melalui efeknya terhadap kandungan dan tekanan osmotik cairan tubuh organisme akuatik (Poxton, 2003). Pada perairan pesisir seperti di Kecamatan Pulau Derawan, nilai salinitas sangat dipengaruhi oleh masukan air tawar dari sungai. Dari Tabel 3 dan Gambar 7b terlihat bahwa salinitas air yang rendah (kurang dari $10 \mathrm{ppt}$ ) dijumpai di kawasan pertambakan yang letaknya berada di tepi sungai dan salinitas air yang relatif lebih tinggi (lebih dari $10 \mathrm{ppt}$ ) dijumpai di kawasan tambak yang berada relatif lebih jauh dari sungai sebagai sumber air tambak.
Udang windu, udang vaname, bandeng, dan rumput laut merupakan organisme eurihalin, namun karena dibudidayakan untuk tujuan komersial, kisaran salinitas yang optimum perlu dipertahankan. Udang windu mampu menyesuaikan diri terhadap salinitas 3-45 ppt (Tseng, 1987 dalam Poernomo, 1988), namun untuk pertumbuhan optimum diperlukan salinitas 1525 ppt (Poernomo, 1988). Udang vaname umumnya tumbuh optimum pada salinitas 15-20 ppt (Bray et al., 1994). Ikan bandeng tumbuh optimal pada salinitas 15-25 ppt. Salinitas optimum untuk rumput laut adalah 15-25 ppt (Anonymous, 1991). Dengan demikian, secara umum salinitas tambak di Kecamatan Pulau Derawan dapat mendukung usaha budidaya udang windu, udang vaname, dan ikan bandeng (Tabel 3).

Oksigen terlarut sangat esensial bagi pernapasan dan merupakan salah satu komponen utama dalam metabolisme akuatik. Kebutuhan organisme akan oksigen terlarut sangat bervariasi bergantung kepada jenis, stadium, dan aktivitasnya. Secara umum, organisme akuatik yang dibudidayakan di tambak membutuhkan kandungan oksigen terlarut yang lebih besar $3 \mathrm{mg} / \mathrm{L}$. Kandungan oksigen terlarut di tambak sangat bervariasi dari $6,07 \mathrm{mg} / \mathrm{L}$ sampai $7,80 \mathrm{mg} / \mathrm{L}$ dengan rata-rata 6,66 mg/L (Tabel 3, Gambar 7c). Kandungan oksigen terlarut ini sangat mendukung usaha budidaya di tambak Kecamatan Pulau Derawan. 


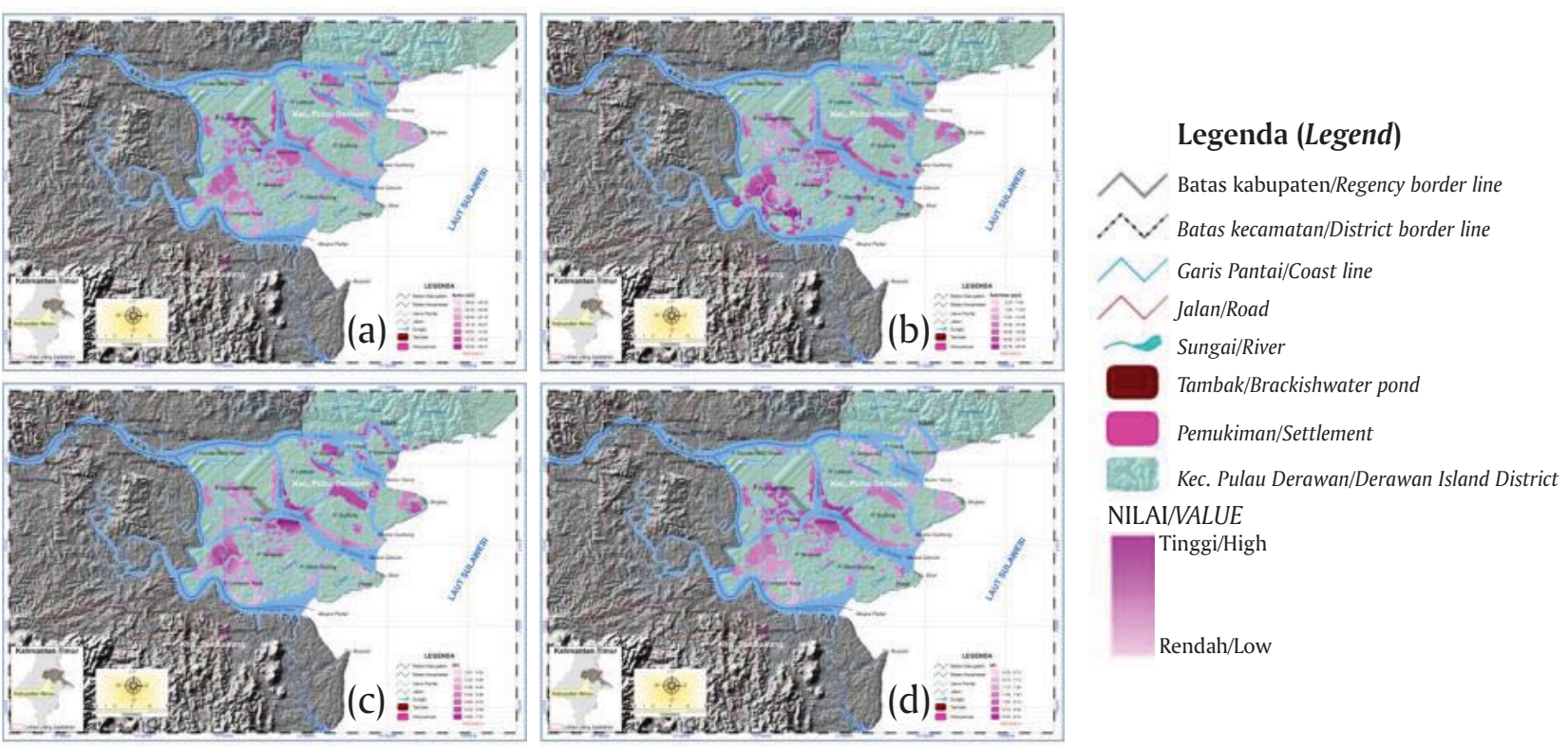

Gambar 7. Peta tematik masing-masing parameter air tambak di Kecamatan Pulau Derawan Kabupaten Berau Provinsi Kalimantan Timur: (a) suhu $\left({ }^{\circ} \mathrm{C}\right)$, (b) salinitas (ppt), (c) oksigen terlarut (mg/L), (d) pH

Figure 7. Thematic map of brackishwater pond water condition for each parameter in Derawan Island District Berau Regency East Kalimantan Province: (a) temperature $\left({ }^{\circ} \mathrm{C}\right)$, (b) salinity (ppt), (c) dissolved oxygen $(m g / L),(d) p H$

Tabel 3. Kualitas air di kawasan pertambakan Kecamatan Pulau Derawan Kabupaten Berau Provinsi Kalimantan Timur $(\mathrm{n}=48)$

Table 3. Water quality of brackishwater ponds in Derawan Island District Berau Regency East Kalimantan Province $(n=48)$

\begin{tabular}{lcccc}
\hline \multicolumn{1}{c}{$\begin{array}{c}\text { Peubah } \\
\text { Variables }\end{array}$} & $\begin{array}{c}\text { Minimum } \\
\text { Minimum }\end{array}$ & $\begin{array}{c}\text { Maksimum } \\
\text { Maximum }\end{array}$ & $\begin{array}{c}\text { Rata-rata } \\
\text { Average }\end{array}$ & $\begin{array}{c}\text { Standar deviasi } \\
\text { Standard deviation }\end{array}$ \\
\hline Suhu (Temperature) $\left({ }^{\circ} \mathrm{C}\right)$ & 28.5 & 35.27 & 30.96 & 1.6804 \\
Salinitas (Salinity) $(\mathrm{ppt})$ & 8.81 & 28.54 & 18.65 & 4.6764 \\
Oksigen terlarut & 6.07 & 7.8 & 6.66 & 0.3589 \\
Dissolved oxygen $(\mathrm{mg} / \mathrm{L})$ & & & & \\
$\mathrm{pH}$ & 6.09 & 9.8 & 8.55 & 0.7075 \\
$\mathrm{NO}_{2}(\mathrm{mg} / \mathrm{L})$ & 0.0044 & 0.0468 & 0.0151 & 0.0075 \\
$\mathrm{NO}_{3}(\mathrm{mg} / \mathrm{L})$ & 0.0012 & 0.5734 & 0.047 & 0.0856 \\
$\mathrm{NH}_{3}(\mathrm{mg} / \mathrm{L})$ & 0.005 & 0.5247 & 0.083 & 0.0831 \\
$\mathrm{PO}_{4}(\mathrm{mg} / \mathrm{L})$ & 0.0004 & 0.4088 & 0.0452 & 0.0955 \\
$\mathrm{Fe}(\mathrm{mg} / \mathrm{L})$ & 0.0015 & 0.149 & 0.0105 & 0.0253 \\
$\mathrm{Bahan}$ organik total & 18.31 & 41.97 & 29.753 & 4.5386 \\
Total organic matter $(\mathrm{mg} / \mathrm{L})$ & & & & \\
Padatan terlarut total & 9.01 & 28.27 & 19.3 & 4.3544 \\
Total suspended solids $(\mathrm{mg} / \mathrm{L})$ & & & & \\
\hline
\end{tabular}


Peubah kualitas air lainnya yang berpengaruh terhadap organisme akuatik adalah $\mathrm{pH}$. Batas toleransi organisme akuatik terhadap $\mathrm{pH}$ bervariasi dan dipengaruhi oleh banyak faktor, antara lain: suhu, oksigen terlarut, alkalinitas, dan adanya anion dan kation, serta jenis dan stadium organisme. Pada umumnya $\mathrm{pH}$ air yang baik bagi organisme akuatik adalah 6,5-9,0; pada $\mathrm{pH}$ 9,5-11,0 dan 4,0-6,0 mengakibatkan produksi rendah dan jika lebih rendah dari 4,0 atau lebih tinggi 11,0 akan meracuni ikan. pH air di kawasan pertambakan Kecamatan Pulau Derawan tergolong netral (Gambar 7d) dan sangat mendukung untuk budidaya di tambak.

Kandungan $\mathrm{NO}_{2}$ air di kawasan pertambakan Kecamatan Pulau Derawan berkisar antara 0,0044 mg/ $\mathrm{L}$ dan $0,0468 \mathrm{mg} / \mathrm{L}$ dengan rata-rata $0,0151 \mathrm{mg} / \mathrm{L}$. Kandungan $\mathrm{NO}_{2}$ pada perairan relatif kecil karena segera dioksidasi menjadi nitrat. Perairan alami mengandung $\mathrm{NO}_{2}$ sekitar $0,001 \mathrm{mg} / \mathrm{L}$ dan sebaliknya tidak melebihi $0,06 \mathrm{mg} / \mathrm{L}$ (Canadian Council of Resource and Environment Ministers, 1987). Di perairan, kandungan $\mathrm{NO}_{2}$ jarang melebihi $1 \mathrm{mg} / \mathrm{L}$ (Sawyer \& McCarty, 1978). Kandungan $\mathrm{NO}_{2}$ yang lebih dari 0,05 $\mathrm{mg} / \mathrm{L}$ dapat bersifat toksik bagi organisme akuatik yang sangat sensitif.

Kandungan $\mathrm{NO}_{3}$ pada perairan tambak Kecamatan Pulau Derawan berkisar antara 0,0012 mg/L dan 0,5734 $\mathrm{mg} / \mathrm{L}$ dengan rata-rata $0,0470 \mathrm{mg} / \mathrm{L}$. Kandungan $\mathrm{NO}_{3}$ lebih dari $5 \mathrm{mg} / \mathrm{L}$ menggambarkan terjadinya pencemaran antropogenik yang berasal dari aktivitas manusia dan tinja hewan. Kandungan $\mathrm{NO}_{3}$ yang lebih dari $0,2 \mathrm{mg} / \mathrm{L}$ dapat mengakibatkan terjadinya eutrofikasi perairan yang selanjutnya menstimulir pertumbuhan alga dan tumbuhan air secara pesat. Kandungan $\mathrm{NO}_{3}$ dalam air tanah dapat mencapai 100 $\mathrm{mg} / \mathrm{L}$. Air hujan memiliki kandungan $\mathrm{NO}_{3}$ sekitar 0,2 $\mathrm{mg} / \mathrm{L}$. Pada perairan yang menerima limpasan air dari daerah pertanian yang banyak mengandung pupuk, kandungan $\mathrm{NO}_{3}$ dapat mencapai $1.000 \mathrm{mg} / \mathrm{L}$.

Kandungan $\mathrm{NH}_{3}$ air tambak di Kecamatan Pulau Derawan berkisar $0,0050-0,5247 \mathrm{mg} / \mathrm{L}$ dengan ratarata $0,0830 \mathrm{mg} / \mathrm{L}$. Kandungan $\mathrm{NH}_{3} 0,05-0,20 \mathrm{mg} / \mathrm{L}$ sudah menghambat pertumbuhan organisme akuatik pada umumnya. Apabila kandungan $\mathrm{NH}_{3}$ lebih dari 0,2 $\mathrm{mg} / \mathrm{L}$; perairan bersifat toksik bagi beberapa jenis ikan (Swayer \& McCarty, 1978). Chanratchakool et al. (1995) menyatakan bahwa kandungan amonia yang diperkenankan untuk budidaya udang windu adalah kurang dari $0,1 \mathrm{mg} / \mathrm{L}$. Ikan tidak dapat bertoleransi terhadap kandungan $\mathrm{NH}_{3}$ yang terlalu tinggi, karena dapat mengganggu proses pengikatan oksigen oleh darah dan pada akhirnya dapat mengakibatkan sufokasi.

Kandungan bahan organik total yang melebihi 60 $\mathrm{mg} / \mathrm{L}$ sudah menunjukkan kualitas air tambak yang menurun. Bahan organik total merupakan sumber terjadinya senyawa yang dapat meracuni organisme yang dibudidayakan dalam proses anaerob atau reaksi reduksi. Namun demikian, secara umum kandungan

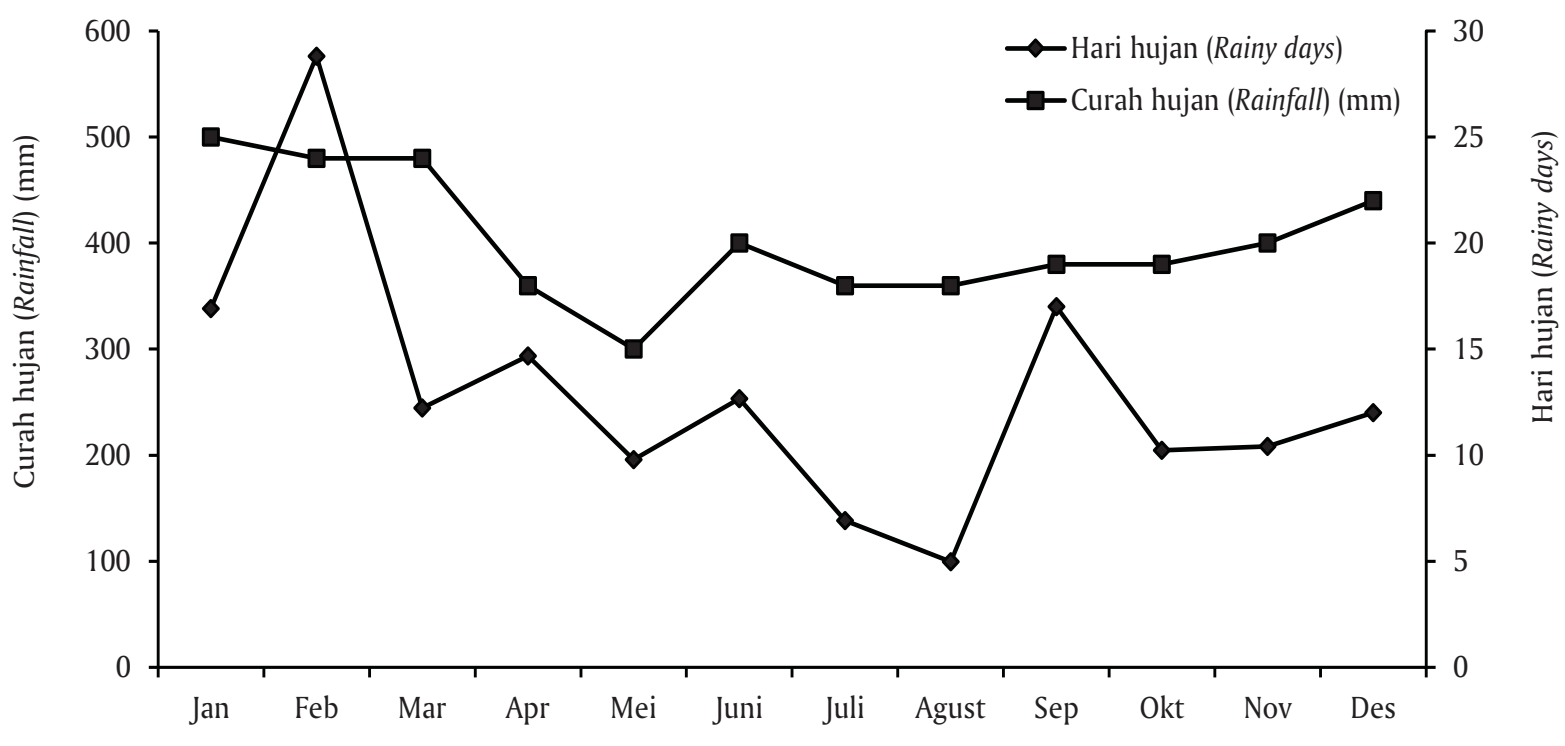

Gambar 8. Curah hujan dan hari hujan bulanan di Kabupaten Berau Provinsi Kalimantan Timur (Diolah dari Anonim, 2009)

Figure 8. Monthly of Rainfall and rainy days in Berau Regency East Kalimantan (Adapted from Anonymous, 2009) 
bahan organik total air masih dapat mendukung usaha tambak.

Padatan terlarut total menggambarkan bahan baik organik maupun non-organik yang terkandung dalam larutan dalam bentuk tersuspensi. Padatan tersuspensi total air tambak di Kecamatan Pulau Derawan berkisar antara 9,01 g/L sampai 28,27 g/L dengan rata-rata 19,30 $\mathrm{g} / \mathrm{L}$. Kandungan padatan tersuspensi total ini cukup tinggi. Secara umum, air payau mengandung padatan tersuspensi total antara $1,5 \mathrm{~g} / \mathrm{L}$ sampai $5,0 \mathrm{~g} / \mathrm{L}$ dan air laut lebih besar dari 5,0 g/L (Effendi, 2003).

\section{Iklim}

Salah satu faktor yang berpengaruh terhadap budidaya tambak termasuk kualitas air tambak adalah iklim, terutama curah hujan dan hari hujan. Curah hujan bulanan di Kabupaten Berau menunjukkan bahwa setiap bulan terjadi hujan dengan intensitas melebihi $60 \mathrm{~mm} /$ bulan (Gambar 8). Curah hujan bulanan dan hari hujan yang rendah dijumpai pada Juli dan Agustus, sedangkan curah hujan dan hari hujan yang lebih tinggi dijumpai pada bulan lainnya.

Curah hujan di Kabupaten Berau mencapai 3.132,4 $\mathrm{mm} /$ tahun. Curah hujan antara 2.000-3.000 mm/tahun dengan bulan kering 2-3 bulan cukup baik untuk budidaya tambak. Tidak dijumpai adanya bulan kering (curah hujan kurang dari $60 \mathrm{~mm}$ ) di Kabupaten Berau. Dengan demikian curah hujan di Kabupaten Berau tergolong kurang mendukung untuk usaha budidaya di tambak. Persiapan tambak adalah salah satu kegiatan yang harus dilakukan sebelum penebaran. Pada saat persiapan tambak dilakukan pengeringan tambak dengan tujuan untuk memperbaiki sifat fisik tanah, meningkatkan mineralisasi bahan organik dan menghilangkan bahan-bahan beracun berupa hidrogen sulfida, amonia, dan metan. Karena itu diperlukan adanya bulan-bulan kering tertentu pada setiap tahun.

\section{Implikasi Pengembangan Lahan Tambak}

Tambak di Kecamatan Pulau Derawan Kabupaten Berau pematangnya harus dibuat tinggi dan lebar agar kuat menahan tekanan air saat terjadi pasang maupun surut, terutama petakan tambak yang berada pada pinggir laut, sungai dan saluran karena pasang surut di daerah ini tergolong tinggi.

Pengelolaan tanah yang dapat dilakukan untuk menurunkan potensi kemasaman dan mengurangi kandungan unsur beracun tanah adalah melalui remediasi yakni berupa pengeringan, perendaman, dan pembilasan tanah maupun melalui pengapuran. Pengapuran bertujuan untuk mengurangi unsur-unsur beracun dan unsur-unsur penyebab kemasaman tanah yang masih tersisa dalam tanah (Mustafa \& Rachmansyah, 2008).
Untuk mengurangi masuknya asam-asam organik dari pematang ke dalam tambak pada saat hujan (terutama setelah panas yang lama), maka pada pematang tambak sebaiknya diberi berm dan ditanami rumput (Mustafa, 2007). Penanaman rumput pada pematang ini juga dapat mengurangi erosi pematang. Bulan Juli dan Agustus adalah saat yang tepat melakukan persiapan tambak di Kecamatan Pulau Derawan Kabupaten Berau.

Agar tambak yang ada di Kecamatan Pulau Derawan Kabupaten Berau dapat berkelanjutan, perlu disisakan jalur hijau dalam hal ini mangrove yang lebarnya sekitar $360 \mathrm{~m}$ di tepi pantai, sesuai dengan rata-rata perbedaan air pasang tinggi yakni $2,77 \mathrm{~m}$; hal ini berdasarkan Pasal 27 Keppres Nomor 32 tahun 1990, minimal 100 $m$ dari kiri kanan sungai besar dan $50 \mathrm{~m}$ dari kiri kanan sungai kecil (Pasal 16 Keppres Nomor 32 tahun 1990) tentang Pengelolaan Kawasan Lindung. Hal ini diperkuat pada Pasal 13 Penjelasan UU RI Nomor 31 (2004) dikatakan bahwa salah satu kawasan konservasi yang terkait dengan perikanan adalah mangrove.

\section{KESIMPULAN}

Karakteristik lahan tambak di kawasan pesisir Kecamatan Pulau Derawan Kabupaten Berau dicirikan dengan topografi yang relatif landai dan elevasi yang tidak terlalu tinggi, kisaran pasang surut tergolong tinggi $(2,77 \mathrm{~m})$ untuk budidaya tambak. Tanah tergolong tanah sulfat masam dengan potensi kemasaman dan kandungan unsur beracun yang tinggi, serta kandungan unsur hara makro yang rendah. Kualitas air seperti suhu, salinitas, $\mathrm{pH}$, dan oksigen terlarut secara umum mendukung usaha budidaya di tambak, kecuali bahan organik total air yang relatif tinggi. Curah hujan dan hari hujan tergolong tinggi yang hampir menyebar secara merata sepanjang tahun, kecuali pada Juli dan Agustus tergolong rendah.

\section{DAFTAR ACUAN}

Abdurachman, A., Umi, H., \& Ishak, J. (2006). Penetapan kadar air tanah dengan metode gravimetrik. Dalam: Kurnia, U. (Eds.). Sifat fisik tanah dan metode analisisnya. Balai Besar Penelitian dan Pengembangan Sumberdaya Lahan Pertanian. Badan Penelitian dan Pengembangan Pertanian. Departemen Pertanian. Bogor, hlm. 131-142.

Ahern, C.R., McElnea, A., \& Baker, D.E. (1998a). Peroxide oxidation combined acidity and sulfate. In: Ahern, C.R., Blunden, B., \& Stone, Y. (Eds.). Acid sulfate soils laboratory methods guidelines. Acid Sulfate Soil Management Advisory Committee, Wollongbar. NSW, p. 4.1-4.17.

Ahern, C.R., McElnea, A., \& Baker, D.E. (1998b). Total oxidisable sulfur. In: Ahern, C.R., Blunden, B., \& 
Stone, Y. (Eds.). Acid sulfate soils laboratory methods guidelines. Acid Sulfate Soil Management Advisory Committee, Wollongbar, NSW. p. 5.1-5.7.

Ahern, C.R., Mcelnea, A.E., \& Sullivan, L.A. (2004). Acid sulfate soils laboratory methods guidelines. In Queensland Acid Sulfate Soils Manual 2004. Department of Natural Resources, Mines and Energy, Indooroopilly, Queensland. Australia, p. A11-I2-4.

Ahern, C.R., \& McElnea, A.E. (2004). Calculated sulfur parameters. In: Acid sulfate soils laboratory methods guidelines. Queensland Department of Natural Resources, Mines and Energy, Indooroopilly, Queensland. Australia, p. B11-1-B11-2.

Akbarzadeh, A., \& Taghizadeh-Mehrjardi, R. (2010). Spatial distribution of some soil properties, using geostatistical methods in Khezrabad Region (Yazd) of Iran. Pro Environment, 3, 100-109.

Anonim. (1991). Mariculture of seaweeds. In: Shokita, S., Kakazu, K., Tomori, A., \& Toma, T. (Eds.), Aquaculture in tropical areas. Midori Shobo Co., Ltd. Tokyo, p. 31-95.

Anonim. (2009). Laporan Tahunan 2008. Dinas Perikanan dan Kelautan Kabupaten Berau. Tanjung Redeb, 64 hlm.

Anonim. (2013). Berau dalam angka. Badan Pusat Statistik Kabupaten Berau. Tanjung Redeb, 288 hlm.

Anuar, A.R., Goh, K.J., Heoh, T.B., \& Ahmed, O.H. (2008). Spatial variability of soil inorganic $\mathrm{N}$ in a mature oil palm plantation in Sabah, Malaysia. American Journal of Applied Sciences, 5(9), 1239-1246.

American Public Health Association [APHA]. (2005). Standard methods for examination of water and wastewater. Twentieth edition APHA-AWWA-WEF. Washington D.C., 1185 pp.

Boyd, C.E. (2008). Pond bottom soil analyses. Global Aquaculture Advocate, September/October, p. 9192.

Bray, W.A., Lawrence, A.L., \& Leung-Trujillo, J.R. (1994). The effect of salinity on growth and survival of Penaeus vannamei, with observations on the interaction of IHHN virus and salinity. Aquaculture, 122, 133-146.

Canadian Council of Resource and Environment Ministers. (1987). Canadian water quality. Canadian Council of Resource and Environment Ministers. Ontario, 92 pp.

Chanratchakool, P., Turnbull, J.F., Funge-Smith, S., \& Limsuwan, C. (1995). Health management in shrimp ponds. Second edition. Aquatic Animal Health Research Institute, Department of Fisheries, Kasetsart University Campus. Bangkok, 111 pp.
Dent, D. (1986). Acid sulphate soils: a baseline for research and development. ILRI Publication 39. International Institute for Land Reclamation and Improvement. Wageningen, 204 pp.

Dong, X.W., Zhang, X.K., Bao, X.L., \& Wang, J.K. (2009). Spatial distribution of soil nutrients after the establishment of sand-fixing shrubs on sand dune. Plant Soil Environment, 55(7), 288-294.

Effendi, H. (2003). Telaah kualitas air bagi pengelolaan sumberdaya dan lingkungan perairan. Penerbit Kanisius (Anggota IKAPI). Yogyakarta, $258 \mathrm{hlm}$.

Ersahin, S. (2003). Comparing ordinary kriging and cokriging to estimate infiltration rate. Soil Science, 67, 1848-1855.

Essington, M.E. (2004). Soil and water chemistry: an integrative approach. CRC Press. Boca Raton, 534 pp.

Huang, X., Skidmore, E.L., \& Tibke, G. (2001). Spatial variability of soil properties along a transect of CRP and continuously cropped land. In: Stott, D.E., Mohtar, R.E., \& Steinhardt, G.C. (Eds.). Sustaining the Global Farm. Selected papers from $10^{\text {th }}$ International Soil Conservation Organization Meeting held May 24-29, 1999 at Purdue University and the USDA-ARS National Soil Erosion Research Laboratory. p. 641-647.

Lin, Y.P., Chang, T.K., \& Teng, T.P. (2001). Characterization of soil lead by comparing sequential Gaussian simulation, simulated annealing simulation and kriging methods. Environmental Geology, 41, 189-199.

Liu, D., Wang, Z., Zhang, B., Song, K., Li, X., Li, J., Li, F., \& Duan, H. (2006). Spatial distribution of soil organic carbon and analysis of related factors in croplands of the black soil region, Northeast China. Agriculture, Ecosystems and Environment, 113, 73-81.

Madyaka, M. (2008). Spatial modelling and prediction of soil salinization using saltmod in a GIS environment. Master of Science Thesis. International Institute for Geo-Information Science and Earth Observation, Enschede the Netherlands. 128 pp.

McElnea, A.E., Ahern, C.R., \& Menzies, N.W. (2002a). Improvements to peroxide oxidation methods for analysing sulfur in acid sulfate soils. Australian Journal of Soil Research, 40, 1115-1132.

McElnea, A.E., Ahern, C.R., \& Menzies, N.W. (2002b). The measurement of actual acidity in acid sulfate soils and the determination of sulfidic acidity in suspension after peroxide oxidation. Australian Journal of Soil Research, 40, 1133-1157.

McElnea, A.E., \& Ahern, C.R. (2004a). KCl extractable $\mathrm{pH}\left(\mathrm{pH}_{\mathrm{KCl}}\right)$ and titratable actual acidity (TAA). In Acid sulfate soils laboratory methods guidelines. 
Queensland Department of Natural Resources, Mines and Energy, Indooroopilly, Queensland. Australia, p. B2-1-B2-3.

McElnea, A.E., \& Ahern, C.R. (2004b). Peroxide pH $\left(\mathrm{pH}_{\mathrm{ox}}\right)$, titratable peroxide acidity (TPA) and excess acid neutralising capacity $\left(\mathrm{ANC}_{\mathrm{E}}\right)$. In: Acid sulfate soils laboratory methods guidelines. Queensland Department of Natural Resources, Mines and Energy, Indooroopilly, Queensland. Australia, p. B31-B3-7.

McElnea, A.E., \& Ahern, C.R. (2004c). Sulfur-peroxide oxidation method. In: Acid sulfate soils laboratory methods guidelines. Queensland Department of Natural Resources, Mines and Energy, Indooroopilly, Queensland. Australia, p. B7-1B7-2.

McElnea, A.E., \& Ahern, C.R. (2004d). Sulfur 1M KCl extraction $\left(\mathrm{S}_{\mathrm{KC}}\right)$. In: Acid sulfate soils laboratory methods guidelines. Queensland Department of Natural Resources, Mines and Energy, Indooroopilly, Queensland. Australia, p. B8-1-B8-2.

Melville, M.D. (1993). Soil laboratory manual. School of Geography, The University of New South Wales, Sydney. Australia, 74 pp.

Menon, R.G. (1973). Soil and water analysis: a laboratory manual for the analysis of soil and water. Proyek Survey O.K.T. Sumatera Selatan. Palembang, $190 \mathrm{pp}$.

Muir, J.F., \& Kapetsky, J.M. (1988). Site selection decisions and project cost: the case of brackish water pond systems. In: Aquaculture engineering technologies for the future. Institution of Chemical Engineers Symposium Series No. 111. EFCE Publication Series No. 66, p. 45-63.

Mustafa, A. (2007). Teknologi pendayagunaan tanah sulfat masam untuk akuakultur berkelanjutan. Orasi Pengukuhan Profesor Riset Bidang Akuakultur. Jakarta, 28 November 2011. Badan Penelitian dan Pengembangan Kelautan dan Perikanan. Jakarta, $97 \mathrm{hlm}$.

Mustafa, A., Rachmansyah, \& Hanafi, A. (2007). Kelayakan lahan untuk budi daya perikanan pesisir. Prosiding Simposium Nasional Hasil Riset Kelautan dan Perikanan tahun 2007. Badan Riset Kelautan dan Perikanan. Jakarta, hlm. 1-29.

Mustafa, A., \& Rachmansyah. (2008). Kebijakan dalam pemanfaatan tanah sulfat masam untuk budidaya tambak. Dalam: Sudradjat, A., Rusastra, I W., \& Budiharsono, S. (Eds.). Analisis kebijakan pembangunan perikanan budidaya. Pusat Riset Perikanan Budidaya. Jakarta, hlm. 1-11.

Mustafa, A., Hasnawi, Paena, M., \& Rachmansyah. (2008). Evaluasi kesesuaian lahan untuk budidaya tambak di Kabupaten Pinrang Provinsi Sulawesi Selatan. J. Ris. Akuakultur, 3(2), 241-261.
Mustafa, A., Hasnawi, \& Tarunamulia. (2010). Karakteristik, kesesuaian dan pengelolaan lahan untuk budidaya tambak di Kabupaten Mamuju Provinsi Sulawesi Barat. Balai Riset Perikanan Budidaya Air Payau. Maros, $29 \mathrm{hlm}$.

Noor, M. (2004). Lahan rawa: sifat dan pengelolaan tanah bermasalah sulfat masam. PT RajaGrafindo Persada. Jakarta, $238 \mathrm{hlm}$.

PanGonzalez, A., Vieira, S.R., \& Taboada, C.M.T. (2000). The effect of cultivation on the spatial variability of selected properties of an umbric horizon. Geoderma, 97(3-4), 273-292.

Parsons, T.R., Maita, Y., \& Lalli, C.M. (1989). A manual of chemical and biological methods for seawater analysis. Pergamon Press. Oxford, 173 pp.

Patrick, W.H.Jr., \& Delaune, R.D. (1977). Chemical and biological redox systems affecting nutrient availability in the coastal wetlands. Geoscience and Man, 18, 131137.

Poernomo, A. (1988). Pembuatan tambak udang di Indonesia. Seri Pengembangan No. 7. Balai Penelitian Perikanan Budidaya Pantai. Maros, $40 \mathrm{hlm}$.

Poernomo, A. (1989). Faktor lingkungan dominan pada budidaya udang intensif. Dalam: Bittner, A. (Ed.). Budidaya air. Yayasan Obor Indonesia. Jakarta, hlm. 66-120.

Pons, L.J. (1973). Outline of genesis, characteristics, classification and improvement of acid sulphate soil. In: Dost, H. (Ed.). Acid sulphate soils. ILRI Publication 18. International Institute for Land Reclamation and Improvement. Wageningen, p. 1-27.

Poxton, M. (2003). Water quality. In: Lucas, J.S., \& Southgate, P.C. (Eds.). Aquaculture: farming aquatic animals and plans. Blackwell Publishing Ltd. Oxford, p. 47-73.

Robinson, T.P., \& Metternicht, G. (2006). Testing the performance of spatial interpolation techniques for mapping soil properties. Computer and Electronics in Agriculture, 50, 97-108.

Sawyer, C.N., \& McCarty, P.L. (1978). Chemistry for environmental engineering. Third edition. McGraw-Hill Book Company. Tokyo, 532 pp.

Soil Survey Staff. (2001). Soil taxonomy, a basic system of soil classification for making and interpreting soil survey. United State Department of Agriculture. Washington D.C., 734 pp.

Sokal, R.R., \& Rohlf, FJ. (1981). Biometry: the principles and practice of statistics in biological research. Second edition: W.H. Freeman and Co. New York, 859 pp.

Sulaeman, Suparto, \& Eviati. (2005). Petunjuk teknis analisis kimia tanah, tanaman, air, dan pupuk. Diedit oleh: Prasetyo, B.H., Santoso, D., \& Widowati, L.R. Balai Penelitian Tanah. Bogor, $136 \mathrm{hlm}$. 
Wiryawan, B., Khazali, M., \& Knight, M. (2005). Menuju kawasan konservasi laut berau kalimantan timur status sumberdaya pesisir dan proses pengembangan KKL. Online; http:// www.rareplanet.org/sites/rareplanet.org/files/ Tugas_COMM_5311_ringkasan_eksekutif.pdf; diakses tanggal 5 Februari 2015.

Zhang, W., Faulkner, J.W., Giri, S.K., Geohring, L.D., \& Steenhuis, T.S. (2009). Effect of soil reduction on phosphorus sorption of an organic-rich silt loam. Soil Science Society of America Journal, 74, 240249.

Zuo, X.A., Zhao, H.L., Zhao, X.Y., Zhang, T.H., Guo, Y.R., Wang, S.K., \& Sam, D. (2008). Spatial pattern and heterogeneity of soil properties in sand dunes under grazing and restoration in Horqin Sandy Land, Northern China. Soil and Tillage Research, 99, 202-212. 
